\title{
Refractory benign esophageal strictures
}

\author{
Gopal Goyal, Surender Sultania, Babulal Meena, Sandeep Nijhawan
}

Department of Gastroenterology, Sawai Man Singh Medical College, Jaipur, Rajasthan, India

\begin{abstract}
Key words Biodegradable stent, dilatation, dysphagia, incisional therapy, refractory benign esophageal strictures, self-expandable metal stent, self-expandable plastic stent
\end{abstract}

\section{Introduction}

Refractory benign esophageal stricture (RBES) is a frequently encountered problem, which negatively affects patient's quality of life and has significant complications such as malnutrition, weight loss, and aspiration pneumonia. ${ }^{[1]}$ Typical benign esophageal strictures are characterized by a cicatricial, anatomic narrowing of the esophagus, which define as either simple or complex strictures. Simple strictures are short $(<2 \mathrm{~cm})$ focal, straight, and can be traversed with an adult endoscope prior to dilatation and are mostly caused by Schatzki rings, esophageal webs, or peptic injury. In contrast, complex strictures are long $(>2 \mathrm{~cm})$, irregular, angulated, or difficult to traverse with an endoscope and mainly caused by

Address for correspondence:

Dr. Sandeep Nijhawan, Department of Gastroenterology,

Sawai Man Singh Medical College, J L N Marg,

Jaipur - 302 004, Rajasthan, India.

E-mail: dr_nijhawan@yahoo.com

\begin{tabular}{|l|c|}
\hline \multicolumn{2}{|c|}{ Access this article online } \\
\hline \multirow{2}{*}{$\begin{array}{l}\text { Website: } \\
\text { www.jdeonline.in }\end{array}$} & Quick Response Code \\
\hline DOI: & \\
10.4103/0976-5042.180084 & \\
\hline
\end{tabular}

surgery, radiotherapy, or corrosive injury. ${ }^{[2]}$ Peptic strictures are common in Western countries and usually respond to few sessions of dilatation. Corrosive strictures are common in developing countries and require repeated sessions of endoscopic dilatation. ${ }^{[3-5]}$

Refractory esophageal strictures are the ones which require more than five sessions of dilatation at 2 weeks interval to achieve a diameter of $14 \mathrm{~mm}$ in the absence of endoscopic evidence of inflammation. Inability to maintain the satisfactory esophageal lumen for 4 weeks after achieving a $14 \mathrm{~mm}$ diameter is a recurrent stricture. ${ }^{[6]}$

The extent of fibrosis of the esophageal wall is an important determinant of stricture severity, maximum wall thickness of $9 \mathrm{~mm}$, or more require a higher number of dilatation sessions than those with $<9 \mathrm{~mm}$ on computed tomography scan [Figure 1]. ${ }^{[7]}$ Endoscopic ultrasonography gives more detailed examination of the full thickness of the esophageal

This is an open access article distributed under the terms of the Creative Commons Attribution-NonCommercial-ShareAlike 3.0 License, which allows others to remix, tweak, and build upon the work non-commercially, as long as the author is credited and the new creations are licensed under the identical terms.

For reprints contact: reprints@medknow.com

How to cite this article: Goyal G, Sultania S, Meena B, Nijhawan S. Refractory benign esophageal strictures. J Dig Endosc 2016;7:1-5. 
wall, the maximum wall thickness has been found to be greater in patients with corrosive and postradiation strictures as compared to patients with peptic strictures. Those patients with involvement of muscularis propria require more sessions of dilatation as compared to patients having involvement of mucosa and submucosa [Figure 2]. ${ }^{[8]}$

Serial endoscopic dilatation with bougies or balloons has been the standard treatment for esophageal strictures. In patients with benign simple strictures, dilatation gives good relief in 85-93\% of cases. ${ }^{[9]}$ Dilatation appears less effective in those with radiation- or corrosive-induced complex strictures. The recurrence rate reaches to $30-40 \%$ during long-term follow-up, especially in complex strictures. ${ }^{[3]}$

Those patients who fail after serial dilatation with bougies or balloons will come to the category of refractory strictures. Adding local steroid injection followed by dilatation is found to decrease the number and frequency of dilatation in peptic strictures [Table 1]. ${ }^{[10,11]}$ Intralesional steroid injection followed by dilatation has been found to be useful in patients with corrosive strictures in nonrandomized trial, ${ }^{[13,14]}$ but its usefulness could not be proved in a randomized controlled trial [Table 2]. ${ }^{[15]}$ Similarly, adding local steroid injection to dilatation did not result in clinical benefit in patients of anastomotic strictures. ${ }^{[12]}$ Incisional therapy can be performed for short strictures $(<1 \mathrm{~cm})$ using needle knife or tip of the polypectomy snare. It has been found to be useful and safe in short anastomotic strictures, the results are comparable to dilatation. ${ }^{[16]}$

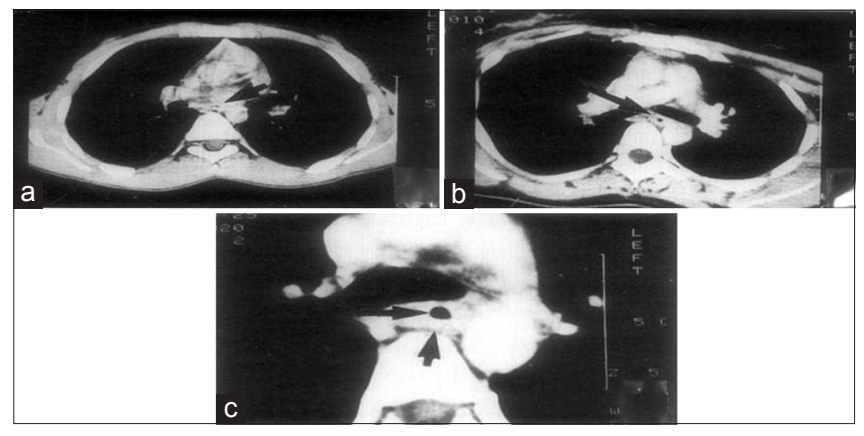

Figure 1: Computed tomography Images of esophageal wall thickness in benign esophageal stricture reproduced from Lahoti et al. ${ }^{[7]}$ (a) Normal esophageal wall (arrow). (b) Mid increase in esophageal wall thickness (arrow). (c) Marked increase in esophageal wall thickness note the esophageal lumen (long arrow) and the outer limit of thickened esophageal wall (short arrow)
Self-expandable stents work on the principle of persistent dilatation till the inflammation subsides. The advantage is avoiding repeated sessions of dilatations. Uncovered self-expandable metal stents (SEMS) have a high complication rate (up to $80 \%$ ) due to hyperplasic tissue in growth; therefore, fully covered SEMS (FCSEMS) are preferable but studies with FCSEMS showed high migration rate with lower clinical success [Table 3]. ${ }^{[17-22]}$

To overcome the problem of hyperplastic tissue reaction, self-expandable plastic stents (SEPS) were introduced. A meta-analysis concluded SEPS to be technically successful in $98 \%$ with $50 \%$ clinical success and $9 \%$ major complications. ${ }^{[23]}$ Another review showed similar technical and clinical success but stent migration in one-third of patients [Table 4]. ${ }^{[24-36]}$

Biodegradable stents (BD) are the alternative to SEPS, they are either Polydioxanone BD stent or Poly-L-lactic acid BD stent. Their degradation occurs by hydrolysis, which starts after 4-5 weeks and dissolves over a period of 2-3 months. Limitations of BD stents are low radial force contributing to early stricture recurrence and their high cost. Sequential BD stent placement is an effective alternative to avoid the burden of frequent dilatation.

The technical success rate of $\mathrm{BD}$ stents in various studies ranges from 85 to $100 \%$ with median $96 \%$ and clinical success rate

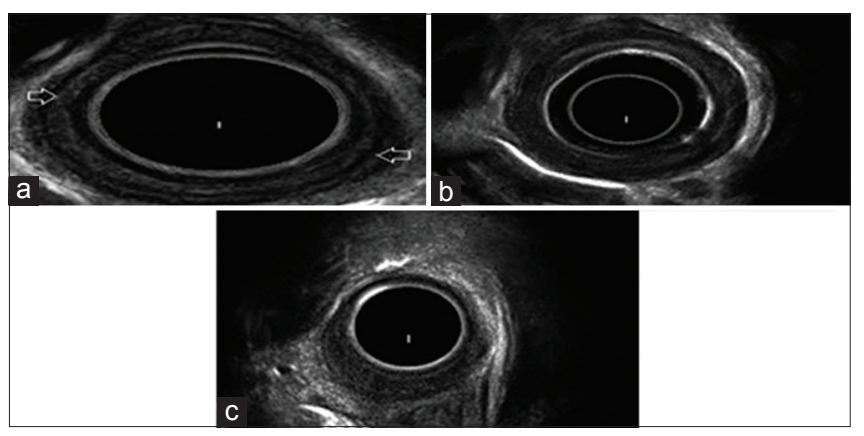

Figure 2: Endoscopic ultrasonography images of benign esophageal stricture reproduced from Rana et al. ${ }^{[8]}$ (a) Endoscopic ultrasonography in a patient with peptic stricture showing the involvement of the mucosa and submucosa. Muscularis propria is seen as hypoechoic layer (arrows). (b) Endoscopic ultrasonography in a patient with corrosive stricture showing involvement of the muscularis propria of esophagus with thickened esophageal wall. (c) Endoscopic ultrasonography in a patient with postradiation stricture showing involvement of all the layers of esophagus with thickened esophageal wall

\begin{tabular}{|c|c|c|c|c|c|}
\hline Author & Year & Type of study & $\begin{array}{l}\text { Number of } \\
\text { patients }\end{array}$ & $\begin{array}{l}\text { Type of } \\
\text { stricture }\end{array}$ & Results \\
\hline Dunne et al. ${ }^{[11]}$ & 1999 & $\begin{array}{l}\text { Prospective randomized (steroid } \\
\text { group and control group) }\end{array}$ & 42 & Peptic & $\begin{array}{l}\text { Decreased dilation frequency in steroid } \\
\text { group from } 6 \text { to } 2 \text { at } 1 \text { year }\end{array}$ \\
\hline Ramage et al...$^{[10]}$ & 2005 & $\begin{array}{l}\text { Prospective double blind randomized } \\
\text { (steroid group and shame group) }\end{array}$ & 30 & Peptic & $\begin{array}{l}\text { Decreased frequency of repeat dilation } 13 \% \\
\text { in steroid group versus } 60 \% \text { in shame group }\end{array}$ \\
\hline Hirdes et al. ${ }^{[12]}$ & 2013 & Double-blind trial & 60 & Anastomotic & Did not result in clinical benefit \\
\hline
\end{tabular}




\begin{tabular}{|c|c|c|c|c|}
\hline Author & Year & Type of study & Number of patients & Results \\
\hline Kochhar et al.. ${ }^{[13]}$ & 1999 & Nonrandomized & 70 & $\begin{array}{l}\text { Median periodic dilation index decreased } \\
\text { significantly from } 1.67 \text { to } 0.32\end{array}$ \\
\hline Kochhar and Makharia ${ }^{[14]}$ & 2002 & Nonrandomized & 29 & $\begin{array}{l}\text { Median periodic dilation index decreased } \\
\text { from } 1.24 \text { to } 0.53\end{array}$ \\
\hline Camargo et al. ${ }^{[15]}$ & 2003 & $\begin{array}{l}\text { Randomized (Group A - dilation } \\
\text { with steroid Group B - dilation } \\
\text { with saline solution injection) }\end{array}$ & 14 & $\begin{array}{l}\text { No statistically difference in dilation frequency } \\
\text { and dysphagia between the two groups }\end{array}$ \\
\hline
\end{tabular}

\begin{tabular}{|c|c|c|c|c|c|c|}
\hline Author & Year & Study design & $\begin{array}{l}\text { Number of } \\
\text { patients }\end{array}$ & $\begin{array}{l}\text { Duration of stent } \\
\text { placement (days) }\end{array}$ & $\begin{array}{c}\text { Early stent } \\
\text { migration }(\%)^{\mathrm{a}}\end{array}$ & $\begin{array}{c}\text { Clinical success, } \\
n(\%)^{\mathrm{b}}\end{array}$ \\
\hline Song et al. ${ }^{[17]}$ & 2000 & Prospective & 25 & 56 & 12 & $12(48)$ \\
\hline Eloubeidi and Lopes ${ }^{[18]}$ & 2009 & Prospective & 7 & 46 & 36 & $2(29)$ \\
\hline Kim et al. ${ }^{[19]}$ & 2009 & Prospective & 55 & 60 & 25.4 & $17(31)$ \\
\hline Bakken et al. ${ }^{[20]}$ & 2010 & Retrospective & 7 & 67 & 50 & $2(29)$ \\
\hline Eloubeidi et al..[21] & 2011 & Retrospective & 10 & - & 37 & $2(21)$ \\
\hline Hirdes et al. ${ }^{[22]}$ & 2012 & Prospective & 15 & 86 & 33.3 & $0(0)$ \\
\hline
\end{tabular}

Early stent migration was defined as the occurrence of stent migration within 4 weeks from stent placement. Clinical success was defined as clinical remission without the need for further endoscopic dilation or surgery after stent removal or migration

\begin{tabular}{|c|c|c|c|c|c|c|c|}
\hline Authors & Years & Study design & $\begin{array}{c}\text { Number of } \\
\text { patients }\end{array}$ & $\begin{array}{l}\text { Technical } \\
\text { success }^{a}\end{array}$ & $\begin{array}{l}\text { Early stent } \\
\text { migration }^{\text {b }}\end{array}$ & Reintervention & Clinical success $^{c}$ \\
\hline Broto et al. ${ }^{[25]}$ & 2003 & Retrospective & 10 & $10(100)$ & $2(20)$ & $6(50)$ & $5(50)$ \\
\hline Evrard et al. ${ }^{[26]}$ & 2004 & Prospective & 17 & $17(100)$ & $5(29)$ & $5(29)$ & $13(76)$ \\
\hline Repici et al. ${ }^{[27]}$ & 2004 & Prospective & 15 & $15(100)$ & $1(7)$ & $1(7)$ & $12(80)$ \\
\hline Triester et al. ${ }^{[28]}$ & 2006 & Retrospective & 5 & $5(100)$ & $2(40)$ & $2(40)$ & $0(0)$ \\
\hline Barthel et al. ${ }^{[29]}$ & 2008 & Retrospective & 8 & $8(100)$ & - & $4(50)$ & $1(13)$ \\
\hline Dua et al. ${ }^{[30]}$ & 2008 & Retrospective & 40 & $38(95)$ & - & $23(58)$ & $12(30)$ \\
\hline Martin et al. ${ }^{[31]}$ & 2008 & Retrospective & 18 & $18(100)$ & $1(6)$ & $2(11)$ & $17(94)$ \\
\hline García-Cano ${ }^{[32]}$ & 2008 & Retrospective & 4 & $4(100)$ & $3(75)$ & $4(100)$ & $2(50)$ \\
\hline Karbowski et al. ${ }^{[33]}$ & 2008 & Retrospective & 12 & $12(100)$ & $5(42)$ & - & $5(42)$ \\
\hline Oh et al..$^{[34]}$ & 2010 & Prospective & 13 & $13(100)$ & $4(31)$ & - & $3(23)$ \\
\hline van Boeckel et al. ${ }^{[35]}$ & 2011 & Prospective & 20 & $19(95)$ & $5(25)$ & - & $6(30)$ \\
\hline Canena et al. ${ }^{[36]}$ & 2012 & Prospective & 10 & $10(100)$ & $6(60)$ & $9(90)$ & $1(10)$ \\
\hline Total & & & 172 & 169 & $39(31)$ & $56(44)$ & $77(45)$ \\
\hline
\end{tabular}

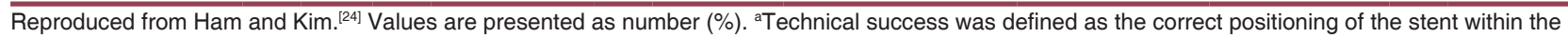
stricture, ${ }^{b}$ Early stent migration was defined as the occurrence of stent migration within 4 weeks from stent placement, ${ }^{c} \mathrm{Clinical}$ success was defined as clinical remission without the need for further endoscopic dilation or surgery after stent removal or migration

ranges from 25 to $100 \%$ with median $47 \%$ [Table 5]. ${ }^{[24,35-43]} \mathrm{A}$ study comparing SEPS and BD stents showed clinical relief of dysphagia in $30 \%$ and $33 \%$ patients, respectively, of patients with RBES. ${ }^{[35]}$ A prospective multicenter study compared temporary placement of three different SEPS (FCSEMS, SEPS, $\mathrm{BD})$ for the treatment of RBES. These stents were placed for 12 weeks. Short-term benefit was comparable for all three stents at 8-9 weeks, long-term benefit could be achieved with BD and FCSEMS but not with SEPS. ${ }^{[36]}$ The technical success was 100\% among all 3 stents long-term clinical success was higher with FCSEMS (40\%) than BD stents (30\%) and least with SEPS (10\%). The migration rates of SEPS, FCSEMS, and BD were $18 \%, 9 \%$, and $6 \%$, respectively.

The cost of $\mathrm{BD}$ stent is an important issue, especially in developing countries. Cost of FCSEMS and SEPS are $1000 \$$
(USD) and $400 \$$ (USD), respectively, whereas the cost of BD stent is around $900 £$ (pound).

The duration of stent placement in RBES is till the inflammation subsides. Strictures longer than $5 \mathrm{~cm}$ may require longer duration of stenting. The duration of stent placement ranges from 12 to 16 weeks. The other factors such as the etiology of stricture and severity of inflammation also affect the outcome of stent placement.

\section{Summary}

All patients of RBESs except anastomotic stricture after the failure of conventional dilatation treatment should be subjected to three sessions of dilatation with intralesional four quadrant triamcinolone injections. Incisional therapy (maximum three 


\begin{tabular}{|c|c|c|c|c|c|c|c|c|}
\hline Authors & Year & Study design & Stent type & $\begin{array}{l}\text { Number } \\
\text { of patient }\end{array}$ & $\begin{array}{l}\text { Technical } \\
\text { success }^{\mathrm{a}}\end{array}$ & $\begin{array}{l}\text { Early stent } \\
\text { migration }^{b}\end{array}$ & $\begin{array}{c}\text { Tissue } \\
\text { hyperplasia }\end{array}$ & $\begin{array}{c}\text { Clinical } \\
\text { success }^{c}\end{array}$ \\
\hline Tanaka et al. ${ }^{[38]}$ & 2006 & Retrospective & PLLA & 2 & $2(100)$ & $2(100)$ & $0(0)$ & $2(100)$ \\
\hline Saito et al. ${ }^{[39]}$ & 2007 & Prospective & PLLA & 13 & $13(100)$ & $10(77)$ & $0(0)$ & $13(100)$ \\
\hline Saito et al. ${ }^{[40]}$ & 2008 & Prospective & PLLA & 2 & $2(100)$ & $0(0)$ & $0(0)$ & $2(100)$ \\
\hline Repici et al. ${ }^{[37]}$ & 2010 & Retrospective & ELLA & 21 & $21(100)$ & $2(10)$ & $1(5)$ & $9(43)$ \\
\hline van Boeckel et al. ${ }^{[35]}$ & 2011 & Retrospective & ELLA & 18 & $16(85)$ & $4(22)$ & $2(11)$ & $6(33)$ \\
\hline van Hooft et al. ${ }^{[41]}$ & 2011 & & ELLA & 10 & $10(100)$ & $0(0)$ & $2(20)$ & $6(60)$ \\
\hline Canena et al. ${ }^{[36]}$ & 2012 & Retrospective & ELLA & 10 & $10(100)$ & $2(20)$ & $3(30)$ & $3(30)$ \\
\hline Hirdes et al. ${ }^{[42]}$ & 2012 & Retrospective & ELLA & 28 & $26(93)$ & $3(11)$ & - & $7(25)$ \\
\hline Karakan et al. ${ }^{[43]}$ & 2013 & Retrospective & ELLA & 7 & $7(100)$ & $0(0)$ & $3(43)$ & $4(57)$ \\
\hline Total & & & & 111 & $107(96)$ & $23(21)$ & $11(13)$ & $52(47)$ \\
\hline
\end{tabular}

Reproduced from Ham and Kim. ${ }^{[24]}$ a Technical success was defined as the correct positioning of the stent within the stricture, ${ }^{\mathrm{b}}$ Early stent migration was defined as the occurrence of stent migration within 4 weeks from stent placement, ${ }^{\circ} \mathrm{Clinical}$ success was defined as clinical remission without the need for further endoscopic dilation or surgery after stent removal or migration. PLLA=Poly-L-lactic acid

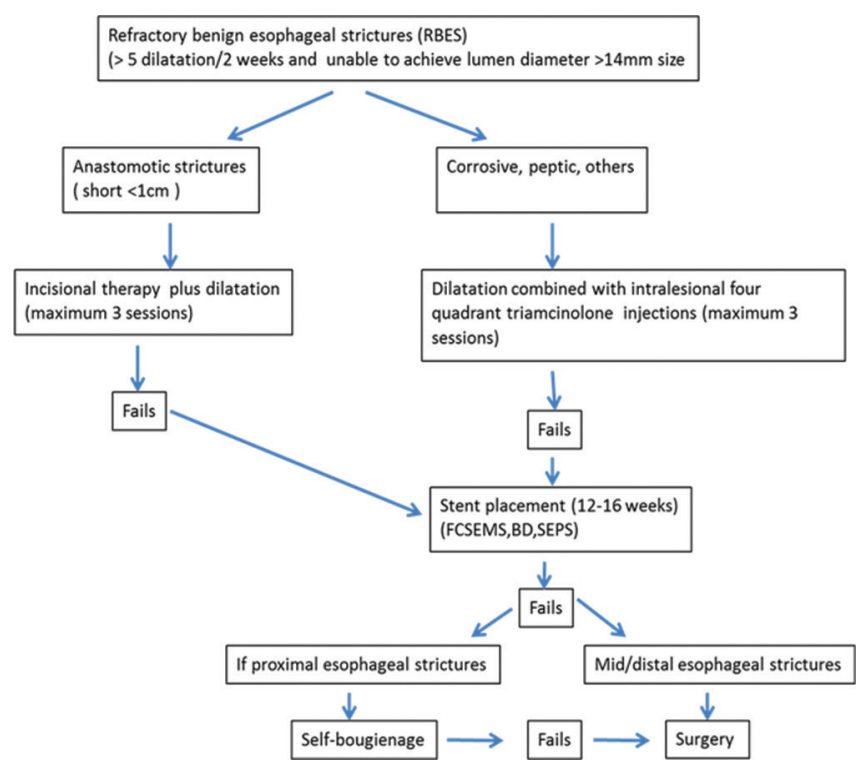

Figure 3: Algorithm for management of refractory benign esophageal strictures (original) FCSEMS: Fully covered self-expandable metallic stents; BD: Biodegradable stents SEPS: Self-expandable plastic stents

sessions) is recommended for short $(<1 \mathrm{~cm})$ anastomotic strictures. Temporary placement of fully covered metallic stent should be tried if the above treatment fails and BD stent may be an option in these cases. Occasional patients with proximal esophageal refractory strictures may do self-bougienage when all these above treatment options fail. Most of the patients of RBES respond to above-mentioned treatment and occasional patient may require surgery as the final treatment option. An algorithm for the management of RBES is given in Figure 3.

\section{Financial support and sponsorship}

Nil.

\section{Conflicts of interest}

There are no conflicts of interest.

\section{References}

1. Siersema PD. Treatment options for esophageal strictures. Nat Clin Pract Gastroenterol Hepatol 2008;5:142-52.

2. Hirdes MM, Vleggaar FP, Siersema PD. Stent placement for esophageal strictures: An update. Expert Rev Med Devices 2011;8:733-55.

3. Patterson DJ, Graham DY, Smith JL, Schwartz JT, Alpert E, Lanza FL, et al. Natural history of benign esophageal stricture treated by dilatation. Gastroenterology 1983;85:346-50.

4. Williamson RC. The management of peptic oesophageal stricture. Br J Surg 1975;62:448-54.

5. Broor SL, Kumar A, Chari ST, Singal A, Misra SP, Kumar N, et al. Corrosive oesophageal strictures following acid ingestion: Clinical profile and results of endoscopic dilatation. J Gastroenterol Hepatol 1989;4:55-61.

6. Kochman ML, McClave SA, Boyce HW. The refractory and the recurrent esophageal stricture: A definition. Gastrointest Endosc 2005;62:474-5.

7. Lahoti D, Broor SL, Basu PP, Gupta A, Sharma R, Pant CS. Corrosive esophageal strictures: Predictors of response to endoscopic dilation. Gastrointest Endosc 1995;41:196-200.

8. Rana SS, Bhasin DK, Singh K. Role of endoscopic ultrasonography (EUS) in management of benign esophageal strictures. Ann Gastroenterol 2011;24:280-284.

9. Riley SA, Attwood SE. Guidelines on the use of oesophageal dilatation in clinical practice. Gut 2004;53 Suppl 1:11-6.

10. RamageJIJr., Rumalla A, BaronTH,Pochron NL,Zinsmeister AR, MurrayJA, et al. A prospective, randomized, double-blind, placebo-controlled trial of endoscopic steroid injection therapy for recalcitrant esophageal peptic strictures. Am J Gastroenterol 2005;100:2419-25.

11. Dunne D, Rupp T, Rex D. Five year follow up of prospective randomized trial of savory dilations with or without intralesional steroids of benign gastroesophageal reflux strictures. Gastroenterology 1999;116:A152.

12. Hirdes MM, van Hooft JE, Koornstra JJ, Timmer R, Leenders M, Weersma RK, et al. Endoscopic corticosteroid injections do not reduce dysphagia after endoscopic dilation therapy in patients with benign esophagogastric anastomotic strictures. Clin Gastroenterol Hepatol 2013;11:795-801.

13. Kochhar R, Ray JD, Sriram PV, Kumar S, Singh K. Intralesional steroids augment the effects of endoscopic dilation in corrosive esophageal strictures. Gastrointest Endosc 1999;49 (4 Pt 1):509-13.

14. Kochhar R, Makharia GK. Usefulness of intralesional triamcinolone in treatment of benign esophageal strictures. Gastrointest Endosc 2002;56:829-34.

15. Camargo MA, Lopes LR, Grangeia Tde A, Andreollo NA, Brandalise NA. Use of corticosteroids after esophageal dilations on patients with 
corrosive stenosis: Prospective, randomized and double-blind study. Rev Assoc Med Bras 2003;49:286-92.

16. Hordijk ML, Siersema PD, Tilanus HW, Kuipers EJ. Electrocautery therapy for refractory anastomotic strictures of the esophagus. Gastrointest Endosc 2006;63:157-63.

17. Song HY, Jung HY, Park SI, Kim SB, Lee DH, Kang SG, et al. Covered retrievable expandable nitinol stents in patients with benign esophageal strictures: Initial experience. Radiology 2000;217:551-7.

18. Eloubeidi MA, Lopes TL. Novel removable internally fully covered self-expanding metal esophageal stent: Feasibility, technique of removal, and tissue response in humans. Am J Gastroenterol 2009;104:1374-81.

19. Kim JH, Song HY, Choi EK, Kim KR, Shin JH, Lim JO. Temporary metallic stent placement in the treatment of refractory benign esophageal strictures: Results and factors associated with outcome in 55 patients. Eur Radiol 2009;19:384-90.

20. Bakken JC, Wong Kee Song LM, de Groen PC, Baron TH. Use of a fully covered self-expandable metal stent for the treatment of benign esophageal diseases. Gastrointest Endosc 2010;72:712-20.

21. Eloubeidi MA, Talreja JP, Lopes TL, Al-Awabdy BS, Shami VM, Kahaleh M. Success and complications associated with placement of fully covered removable self-expandable metal stents for benign esophageal diseases (with videos). Gastrointest Endosc 2011;73:673-81.

22. Hirdes MM, Siersema PD, Vleggaar FP. A new fully covered metal stent for the treatment of benign and malignant dysphagia: A prospective follow-up study. Gastrointest Endosc 2012;75:712-8.

23. Repici A, Hassan C, Sharma P, Conio M, Siersema P. Systematic review: The role of self-expanding plastic stents for benign oesophageal strictures. Aliment Pharmacol Ther 2010;31:1268-75.

24. Ham YH, Kim GH. Plastic and biodegradable stents for complex and refractory benign esophageal strictures. Clin Endosc 2014;47:295-300.

25. Broto J, Asensio M, Vernet JM. Results of a new technique in the treatment of severe esophageal stenosis in children: Poliflex stents. J Pediatr Gastroenterol Nutr 2003;37:203-6.

26. Evrard S, Le Moine O, Lazaraki G, Dormann A, El Nakadi I, Devière J. Self-expanding plastic stents for benign esophageal lesions. Gastrointest Endosc 2004;60:894-900.

27. Repici A, Conio M, De Angelis C, Battaglia E, Musso A, Pellicano R, et al. Temporary placement of an expandable polyester silicone-covered stent for treatment of refractory benign esophageal strictures. Gastrointest Endosc 2004;60:513-9.

28. Triester SL, Fleischer DE, Sharma VK. Failure of self-expanding plastic stents in treatment of refractory benign esophageal strictures. Endoscopy 2006;38:533-7.

29. Barthel JS, Kelley ST, Klapman JB. Management of persistent gastroesophageal anastomotic strictures with removable self-expandable polyester silicon-covered (Polyflex) stents: An alternative to serial dilation. Gastrointest Endosc 2008;67:546-52.

30. Dua KS, Vleggaar FP, Santharam R, Siersema PD. Removable self-expanding plastic esophageal stent as a continuous, non-permanent dilator in treating refractory benign esophageal strictures: A prospective two-center study. Am J Gastroenterol 2008;103:2988-94.

31. Martin RC, Woodall C, Duvall R, Scoggins CR. The use of self-expanding silicone stents in esophagectomy strictures: Less cost and more efficiency. Ann Thorac Surg 2008;86:436-40.

32. García-Cano J. Dilation of benign strictures in the esophagus and colon with the polyflex stent: A case series study. Dig Dis Sci 2008;53:341-6.

33. Karbowski M, Schembre D, Kozarek R, Ayub K, Low D. Polyflex self-expanding, removable plastic stents: Assessment of treatment efficacy and safety in a variety of benign and malignant conditions of the esophagus. Surg Endosc 2008;22:1326-33.

34. Oh YS, Kochman ML, Ahmad NA, Ginsberg GG. Clinical outcomes after self-expanding plastic stent placement for refractory benign esophageal strictures. Dig Dis Sci 2010;55:1344-8.

35. van Boeckel PG, Vleggaar FP, Siersema PD. A comparison of temporary self-expanding plastic and biodegradable stents for refractory benign esophageal strictures. Clin Gastroenterol Hepatol 2011;9:653-9.

36. Canena JM, Liberato MJ, Rio-Tinto RA, Pinto-Marques PM, Romão CM, Coutinho AV, et al. A comparison of the temporary placement of 3 different self-expanding stents for the treatment of refractory benign esophageal strictures: A prospective multicentre study. BMC Gastroenterol 2012;12:70.

37. Repici A, Vleggaar FP, Hassan C, van Boeckel PG, Romeo F, Pagano N, et al. Efficacy and safety of biodegradable stents for refractory benign esophageal strictures: The BEST (biodegradable esophageal stent) study. Gastrointest Endosc 2010;72:927-34.

38. Tanaka T, Takahashi M, Nitta N, Furukawa A, Andoh A, Saito Y, et al. Newly developed biodegradable stents for benign gastrointestinal tract stenoses: A preliminary clinical trial. Digestion 2006;74:199-205.

39. Saito Y, Tanaka T, Andoh A, Minematsu H, Hata K, Tsujikawa T, et al. Usefulness of biodegradable stents constructed of poly-1-lactic acid monofilaments in patients with benign esophageal stenosis. World J Gastroenterol 2007;13:3977-80.

40. Saito Y, Tanaka T, Andoh A, Minematsu H, Hata K, Tsujikawa T, et al. Novel biodegradable stents for benign esophageal strictures following endoscopic submucosal dissection. Dig Dis Sci 2008;53:330-3.

41. van Hooft JE, van Berge Henegouwen MI, Rauws EA, Bergman JJ, Busch OR, Fockens P. Endoscopic treatment of benign anastomotic esophagogastric strictures with a biodegradable stent. Gastrointest Endosc 2011;73:1043-7.

42. Hirdes MM, Siersema PD, van Boeckel PG, Vleggaar FP. Single and sequential biodegradable stent placement for refractory benign esophageal strictures: A prospective follow-up study. Endoscopy 2012;44:649-54.

43. Karakan T, Utku OG, Dorukoz O, Sen I, Colak B, Erdal H, et al. Biodegradable stents for caustic esophageal strictures: A new therapeutic approach. Dis Esophagus 2013;26:319-22. 